\title{
ENHANCING REMOVAL EFFICIENCY OF AMMONIA AND NITRATE IN SHRIMP FARM WASTEWATER USING BIOFLOC TECHNOLOGY AND EFFECTIVE MICROORGANISM S4 (EM4)
}

\author{
Dian Rahayu Pujiastuti ${ }^{1}$, Nyoman Suwartha ${ }^{1 *}$ \\ ${ }^{1}$ Environmental Engineering Study Program, Department of Civil Engineering, Faculty of \\ Engineering, Universitas Indonesia, Kampus UI Depok, Depok 16424, Indonesia
}

(Received: February 2017/ Revised: June 2017 / Accepted: October 2017)

\begin{abstract}
Shrimp farms generate wastewater which contains high concentrations of ammonia and nitrate produced by feed residue and shrimp excretion. This study aims to analyze concentration changes in ammonia and nitrate in shrimp farm wastewater by applying biofloc technology combined with Effective Microorganisms 4 (EM4). It also aims to determine the optimum concentration of EM4 for reducing ammonia and nitrate concentrations. Laboratory-scale experiments were carried out for 30 days using three $40 \times 25 \times 30 \mathrm{~cm}^{3}$ treatment tanks. Each tank was equipped with a $7 \mathrm{l} / \mathrm{min}$ aerator, a 30 -watt lamp, 15 liters of fresh water, 20 young shrimp, and EM4 concentrations of $3 \mathrm{ml} / 1,5 \mathrm{ml} / 1$, and $7 \mathrm{ml} / 1$, respectively. At the end of the observation period, water parameters were recorded, such as dissolved oxygen (DO) range of 4.11 to 4.48 $\mathrm{mg} / \mathrm{L}, \mathrm{pH}$ range of $7.7-8.4$, and temperature range of $29.1-30.7^{\circ} \mathrm{C}$. Nutrient levels had declined, with the maximum removal of ammonia from the $3 \mathrm{ml} / \mathrm{l}, 5 \mathrm{ml} / \mathrm{l}$, and $7 \mathrm{ml} / \mathrm{l} \mathrm{EM} 4$ concentration tanks of $74.1 \%, 84.2 \%$, and $88.9 \%$, respectively and for nitrates of $68.4 \%, 72.6 \%$, and $83.7 \%$, respectively. Ammonia and nitrate concentrations were reduced to about $0.634 \mathrm{mg} / \mathrm{l}$ and $1.261 \mathrm{mg} / \mathrm{l}$, respectively. Dosage of EM4 of $7 \mathrm{ml} / \mathrm{l}$ was considered to be the optimum concentration for reducing ammonia and nitrate concentration. It can be concluded that the combination of biofloc technology and EM4 is successful in removing ammonia and nitrate waste from shrimp farm wastewater and in maintaining nutrients and water quality at safe levels. This combination therefore has the potential to be used for water recycling in shrimp aquaculture.
\end{abstract}

Keywords: Ammonia; Biofloc technology; EM4; Nitrate; Shrimp farm waste water

\section{INTRODUCTION}

Indonesia is the world's largest maritime nation, with two-thirds of its area being sea. As a result, Indonesia has a variety of types of aquaculture production, one of which is shrimp aquaculture. According to the Ministry of Maritime Affairs and Fisheries, the area of shrimp ponds in Indonesia was around 344,759 ha in 2012 , or about $39.78 \%$ of the potential land available (866,550 ha), with average productivity of about $267 \mathrm{~kg} / \mathrm{ha}$.

However, rapid development of shrimp farms had an impact on the environment, and in particular on marine ecosystems. Shrimp farms produce wastewater with high concentrations of ammonia and nitrate, due to the accumulation of organic material from residual feed containing high protein and from shrimp excrement. High concentrations of ammonia and nitrate were

*Corresponding author's email: nsuwartha@eng.ui.ac.id, Tel: +62-21-7270029, Fax: +62-21-7270028

Permalink/DOI: https://doi.org/10.14716/ijtech.v8i6.685 
found in the aquatic environment causing both nitrification and denitrification (Manahan, 2005). Nitrification is the oxidation process of ammonia into nitrates, while denitrification is the process of decomposition of nitrate and nitrite into nitrogen gas $\left(\mathrm{N}_{2}\right)$ which is then released into the atmosphere. Both of these processes lead to the formation of toxic conditions in the aquatic environment which can cause the death of marine life and disrupt the ecological balance of the environment.

Shrimp stocks in aqua culture require 120 days to be ready for harvest. Pond water is generally replaced every 10 days, but sometimes more frequently, depending on the condition of the shrimp. The more frequently pond water is replaced, the more wastewater is produced, and this leads to increases in ammonia and nitrate concentrations in the environment. The aim of this study is to improve the water quality inside the ponds so that shrimp growth is optimized and the effluent water produced can be reused.

Several treatment techniques have been introduced to improve shrimp pond wastewater, such as biological treatments (for example, settlement ponds and high-rate algae ponds) and a form of chemical treatment commonly known as biofloc technology. Biofloc technology has advantages compared with the conventional water-replacing process that allows ponds to be maintained until harvesting. The main principle applied in biofloc technology is water quality management based on the ability of heterotrophic bacteria to utilize organic and inorganic nitrogen presenting the water (Avnimelech, 2007; de Schryver \& Verstraete, 2009). The principle mechanism of biofloc technology is to flocculate floc particles consisting of microbes, uneaten feed particles, shrimp secretions, and other detritus in the water, by physiochemical forces and polymer matrices (Avnimelech, 2012; Hargreaves, 2013). The process can be achieved by introducing external carbon sources to the aquaculture system to stimulate the growth of heterotrophic bacteria, which then take up nitrogen through the production of microbial protein in the water system (Avnimelech, 1999). Biofloc technology provides two critical servicestreating waste from feeding and providing nutrition from floc consumption (Hargreaves, 2013). The application of biofloc technology in shrimp aquaculture uses microbes to decompose inorganic nitrogen into organic nitrogen which is not toxic and can be used by shrimp as a food source.

EM4 is a type of liquid fertilizer that contains microbes, especially acid bacteria and yeast, and which works through a fermentation mechanism. A mixture of EM4 cultures works inside synergistic action. The use of EM4 is an innovation that can enhance the implementation of biofloc technology. EM4 is a collection of microorganisms that can improve water quality by degrading organic matter and suppressing the growth of pathogenic bacteria. Given these properties, water treatment engineering using biofloc technology combined with EM4 is considered to be a potential new approach that could be used as an alternative method of protecting aquatic, especially marine, ecosystems. The objectives of this study are (1) to determine changes in ammonia and nitrate concentration in shrimp farm wastewater by applying biofloc technology combined with EM4; and (2) to determine the optimum concentration of EM4 for reducing ammonia and nitrate concentration. The result of this study is expected to have practical applications for the reuse of shrimp farm wastewater.

\section{EXPERIMENTAL METHODS}

\subsection{Tank Preparation and Feeding}

This experiment used three $40 \times 25 \times 30 \mathrm{~cm}^{3}$ acrylic treatment tanks containing varying concentrations of EM4: $3 \mathrm{ml} / \mathrm{l} ; 5 \mathrm{ml} / \mathrm{l}$; and $7 \mathrm{ml} / \mathrm{l}$. Each treatment tank was filled with 15 liters of fresh water, 20 young shrimps at post-larva-10 (PL 10) stage, an aerator with a capacity of 7 $1 / \mathrm{min}$, and a $30 \mathrm{~W}$ lamp. Fresh water was used to allow the young shrimp to adapt to their new 
environment and to reduce their level of stress. Feed of approximately $4 \%$ of the shrimp weight was given four times a day, at 7 a.m., 12 p.m., 4 p.m., and 9 p.m. The experiment was conducted over 30 days and with two measurements (in duplo, A and B) under the same conditions and treatment.

\subsection{EM4 Activation and Fermentation Process}

Before pouring the EM4 into the treatment tanks it was activate during molasses and water. The ratio of EM4 to molasses to water was set to $1: 1: 18$. The activation process was conducted by pouring $10 \mathrm{ml} \mathrm{EM} 4,10 \mathrm{ml}$ of molasses, and $180 \mathrm{ml}$ of water into a sealed container and stirring to ensure a well-mixed condition. The fermentation process was continued for between four and seven days, with the longer fermentation time producing a greater number of activated bacteria.

Measurement of the EM4 bacterial concentration in each treatment tank was conducted weekly. The bacterial concentration was measured using the total plate count (TPC) method by ten times dilution.

\subsection{Water Parameters Analysis}

Water parameters were recorded in situ for temperature, $\mathrm{pH}$, and DO. For nitrate and ammonia, samples of water were taken and brought to the laboratory for analysis. The ammonia and nitrate were analyzed once every two days, TPC was analyzed once a week, and control parameters such as temperature, $\mathrm{pH}$, and $\mathrm{DO}$ were analyzed every day. Due to the poured water into each treatment tank was fresh water, the ammonia and nitrate concentrations were expected still to be very low and fairly stable over two-day periods.

\section{RESULTS AND DISCUSSION}

\subsection{Characteristics of the Shrimp Farm Water}

Water parameter data for each treatment tank from the first three days of observation are summarized in Table 1.

Table 1 Characteristics of shrimp farm water

\begin{tabular}{|c|c|c|c|c|c|c|c|c|c|c|}
\hline \multirow{2}{*}{ Treatments } & \multicolumn{10}{|c|}{ Parameter } \\
\hline & \multicolumn{2}{|c|}{ Temperature $\left({ }^{\circ} \mathrm{C}\right)$} & \multicolumn{2}{|c|}{$\mathrm{pH}$} & \multicolumn{2}{|c|}{$\mathrm{DO}(\mathrm{mg} / \mathrm{l})$} & \multicolumn{2}{|c|}{ Ammonia (mg/l) } & \multicolumn{2}{|c|}{ Nitrate (mg/l) } \\
\hline EM4 3ml/1 A & 29.4 & \multirow{2}{*}{29.6} & 7.7 & \multirow{2}{*}{7.7} & 3.580 & \multirow{2}{*}{3.910} & 0.809 & \multirow{2}{*}{0.787} & 1.977 & \multirow{2}{*}{1.712} \\
\hline EM4 3ml/1 B & 29.8 & & 7.7 & & 4.240 & & 0.765 & & 1.447 & \\
\hline EM4 5ml/1 A & 29.4 & \multirow{2}{*}{29.5} & 7.8 & \multirow{2}{*}{7.8} & 3.480 & \multirow{2}{*}{3.945} & 0.764 & \multirow{2}{*}{0.745} & 1.762 & \multirow{2}{*}{1.659} \\
\hline EM4 5ml/1 B & 29.6 & & 7.8 & & 4.410 & & 0.726 & & 1.555 & \\
\hline EM4 7ml/1 A & 29.5 & \multirow{2}{*}{29.6} & 7.8 & \multirow{2}{*}{7.8} & 3.740 & \multirow{2}{*}{3.895} & 0.686 & \multirow{2}{*}{0.779} & 1.735 & \multirow{2}{*}{1.685} \\
\hline $\mathrm{EM} 4$ 7ml/1 B & 29.7 & & 7.8 & & 4.050 & & 0.871 & & 1.635 & \\
\hline
\end{tabular}

As shown in Table 1, the data obtained from the duplo measurements (A and B) for all the five parameters were then merged as the averaged value. It can be seen that for each treatment tank ammonia and nitrate concentrations (indicated by bold characters) exceeded the ideal concentration for shrimp farm water of between $<0.1 \mathrm{ppm}(\mathrm{mg} / \mathrm{l})$ for ammonia and <1.0ppm $(\mathrm{mg} / \mathrm{l})$ for nitrate (Arifin et al., 2007). According to Arifin et al. (2007), a tolerable concentration of ammonia and nitrate in fish farm water is generally about $0.3 \mathrm{mg} / \mathrm{l}$.

\subsection{Ammonia Removal Rate}

Measurement of ammonia was performed every two days, along with probiotic observation. Figure 1 shows the ammonia removal changed overtime for each treatment tank. It can be seen 
that over the first seven days a significant increase in ammonia removal occurred. This increase indicates the decomposition of ammonia by EM4 bacteria.

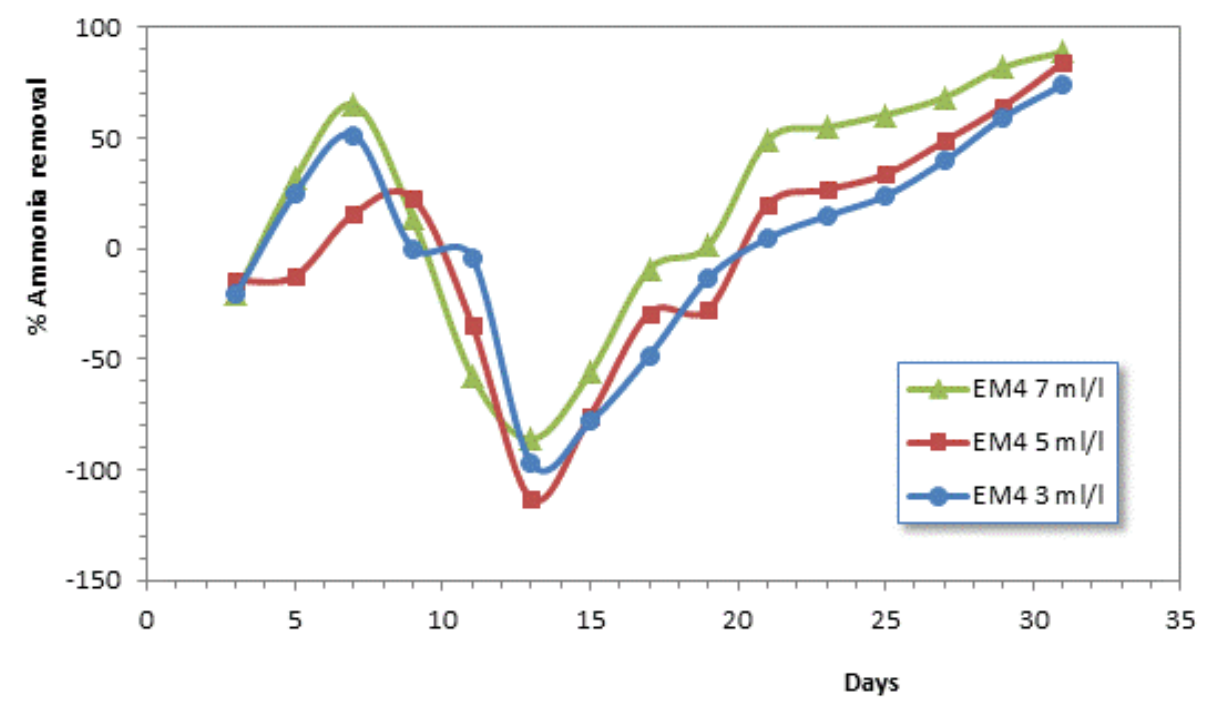

Figure 1 Ammonia removal rate during the 30 day treatment period for each EM4 concentration

However, from the ninth to the thirteenth days, there was a decrease in ammonia removal in all three treatment tanks. This reflected the probiotic bacteria in the EM4 still adapting to the environment and consequent impacts on their growth. This shows that the decomposition process performed by the probiotic bacteria is not perfect and tends to fluctuate. From the measurement on the seventeenth day through to the end of the observation period, the concentration of ammonia in each treatment tank showed significant decrease. The average percentage of ammonia removal at EM4 concentrations of $3 \mathrm{ml} / 1$ and $5 \mathrm{ml} / 1$ were $36.1 \%$ and $46.3 \%$, respectively. However, the largest decrease of ammonia, of $67.3 \%$ with maximum removal of $88.9 \%$, was found in EM4 concentration of $7 \mathrm{ml} / \mathrm{l}$. The ammonia concentration at the end of the observation period was $0.0868 \mathrm{mg} / \mathrm{l}$, meeting the quality standard of specified water sources in shrimp farms of less than $0.3 \mathrm{mg} / \mathrm{l}$ (Arifin et al., 2007).

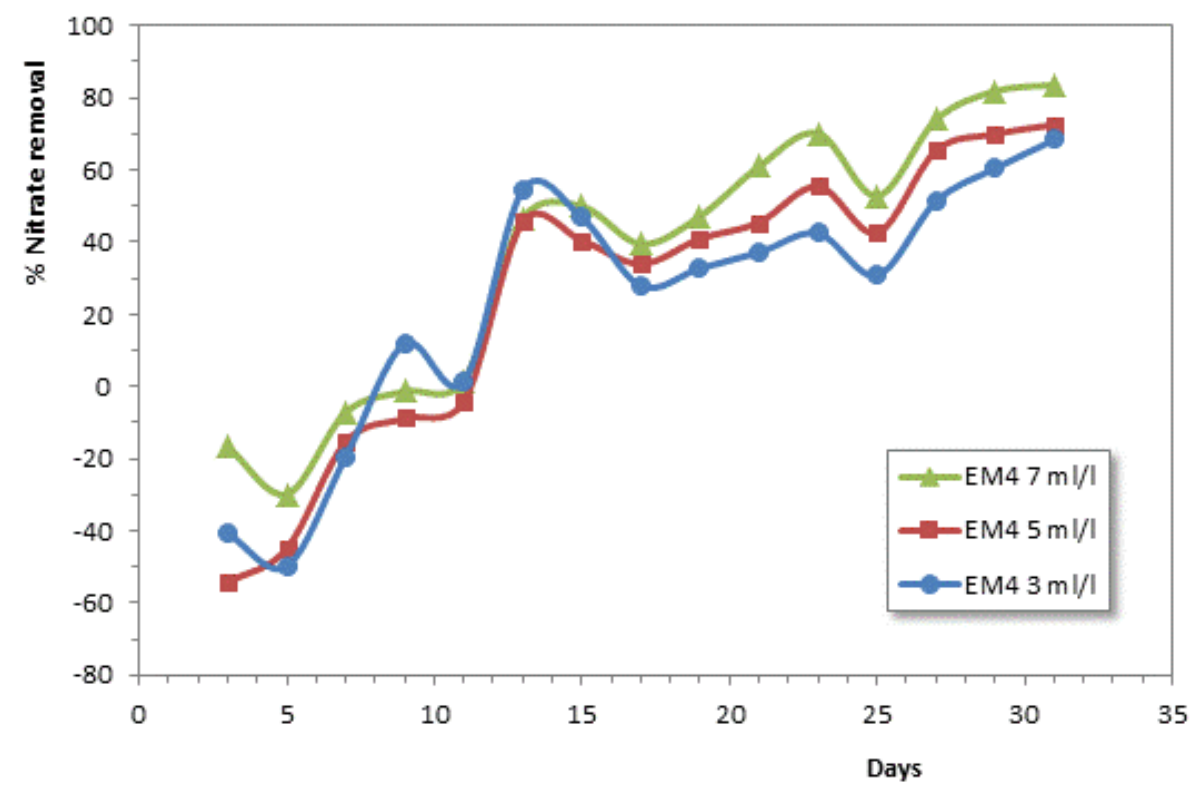

Figure 2 Nitrate removal rate during the 30 day treatment period for each EM4 concentration 


\subsection{Nitrate Removal Rate}

During the 30 days of observation, concentration of nitrate in each treatment tank decreased for all EM4 concentrations (Figure 2). However, in general, the decrease of nitrate concentration fluctuated and was not as significant as the ammonia removal rate.

The decrease of nitrate concentration was found to be largest in the EM4 concentration of 7 $\mathrm{ml} / \mathrm{l}$, with average percentage of nitrate removal of $79.9 \%$. After the final observation (day31) nitrate removal by EM4 $7 \mathrm{ml} / 1$ had risen to $83.7 \%$, while for EM4 concentrations of $3 \mathrm{ml} / \mathrm{l}$ and $5 \mathrm{ml} / \mathrm{l}$ rates of $60.1 \%$ and $69.4 \%$, respectively were found. It can be concluded that EM4 $7 \mathrm{ml} / \mathrm{l}$ is the optimum concentration, as indicated by the most efficient nitrate reduction.

\subsection{EM4 Bacterial Concentration Growth}

As the ammonia and nitrate concentrations changed over the 30 day observation period, EM4 bacterial concentration also increased with time. The growth of EM4 bacterial concentration in each treatment tank is presented in Figure 3.

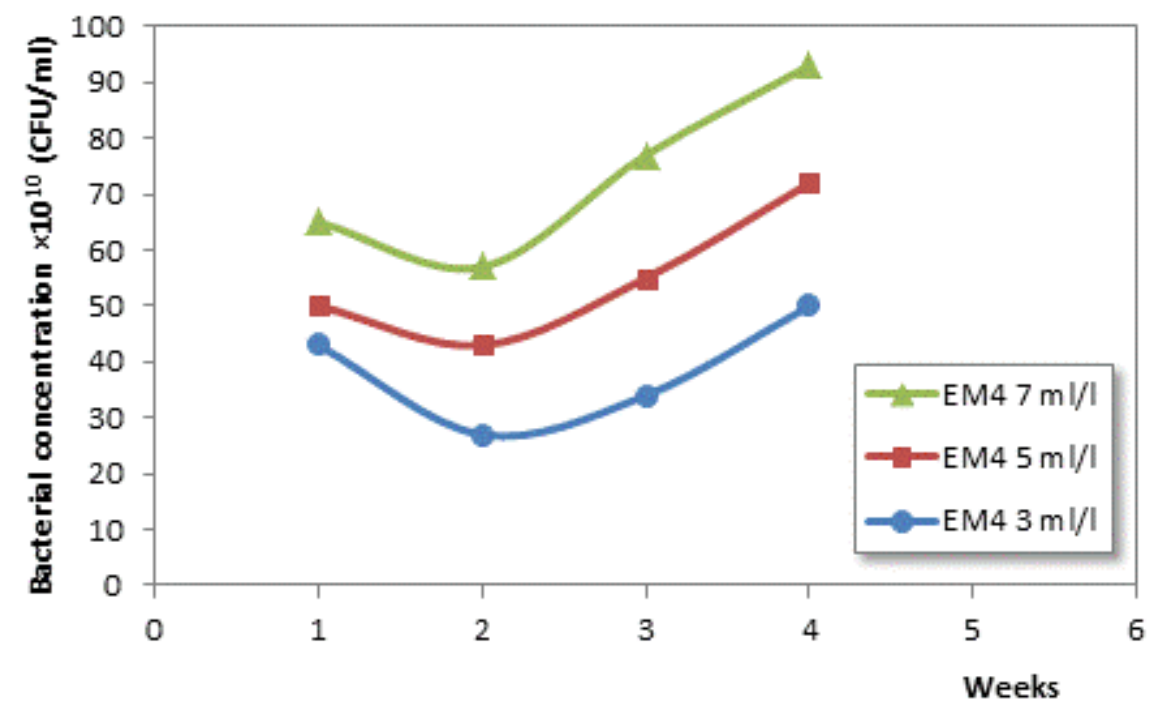

Figure 3 Bacterial concentrations for each EM4 variation

As shown in Figure 3, it is clear that the bacterial concentration growth of EM4 increased significantly over time. From the first to the second week, EM4 concentration was low and decreased. This indicates that EM4 probiotics can be assumed to have been in a lag phase during which they adapted and adjusted to their new environment. This phenomenon is characterized by decreasing amounts of bacteria in a medium (Black, 2002). However, from the third to fourth weeks, bacterial growth tended to continuously increase. This indicates that the EM4 bacteria were in a log or exponential phase, where higher growth rate was affected by $\mathrm{pH}$ and other aspects of the local environment. According to Samodro (2001), the log phase of bacterial growth is marked by increasing $\mathrm{pH}$ of the surrounding environment. In general, the treatment tank containing the EM4 $7 \mathrm{ml} / \mathrm{l}$ showed the most rapid growth compared to the other variations of EM4 concentration. Total bacterial concentration of EM4 $7 \mathrm{ml} / \mathrm{l}$ at the end of the observation was about $93 \times 10^{10}$ colony-forming-units $(\mathrm{CFU}) / \mathrm{ml}$, indicating that EM4 bacteria can decompose ammonia and nitrate more effectively when present in large numbers.

\subsection{Dissolved Oxygen (DO)}

The DO parameter is one of the most important parameters, indicating the level of dissolved oxygen in water. The DO concentration changes over time at each treatment tank are shown in Figure 4. 


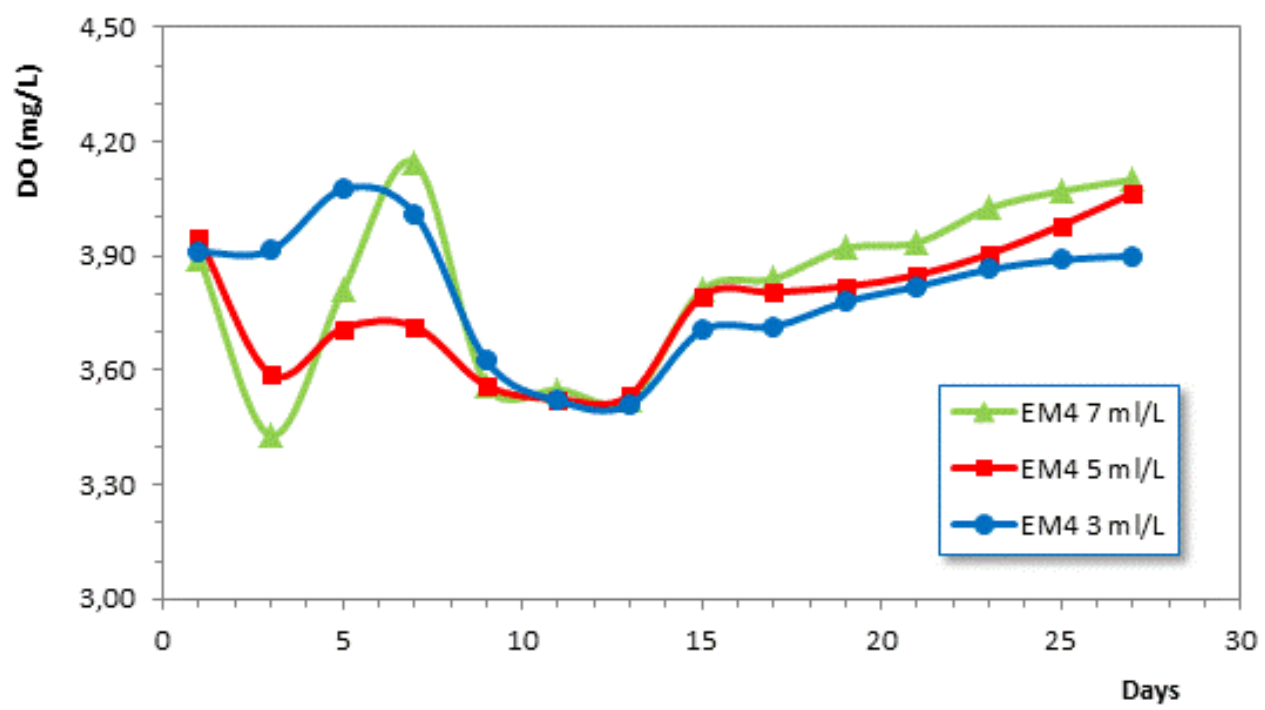

Figure 4 Fluctuation of DO concentrations during the 30-day observation period for each EM4 concentration

In general, it can be seen that the oxygen level in each treatment tank tends to fluctuate. The decrease in DO concentration in the EM4 $7 \mathrm{ml} / \mathrm{l}$ treatment tank between the ninth and thirteenth days resulted from shrimp molting. This caused the oxygen level to decrease, although it was still within the acceptable level for quality of shrimp farm water of $>3.5 \mathrm{ppm}$ (Arifin et al., 2007). The highest DO increment occurred in the EM4 $7 \mathrm{ml} / \mathrm{l}$ treatment tank. DO value in the three treatment tanks, EM4 3ml/l, EM4 $5 \mathrm{ml} / 1$, and EM4 7ml/l, were found to be $4.11 \mathrm{mg} / \mathrm{l}, 4.26$ $\mathrm{mg} / \mathrm{l}$ and $4.48 \mathrm{mg} / \mathrm{l}$, respectively. In general, the results obtained are close to those found in research conducted by Manan et al. (2016).

\section{6. $\mathrm{pH}$}

This parameter indicates the acidity of water, and can affect the decomposition of organic compounds by probiotic bacteria. In this study, different $\mathrm{pH}$ values were obtained for each treatment tank, but they were still within the optimum $\mathrm{pH}$ range for shrimp farming. The fluctuation of $\mathrm{pH}$ value in each treatment tank is presented in Figure 5.

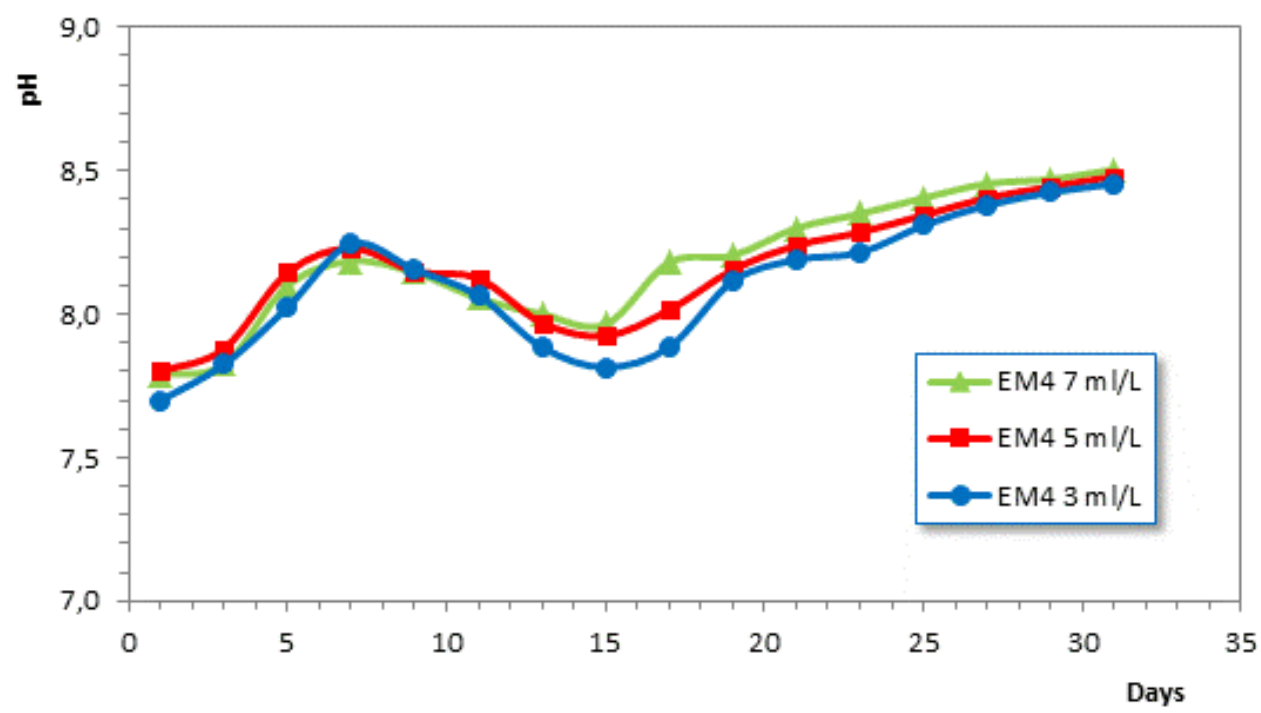

Figure 5 Daily changes of $\mathrm{pH}$ value during the observation period 
In general, the $\mathrm{pH}$ across the treatment tanks ranged from 7.7 to 8.4. Again, this result is similar to those obtained by Manan et al. (2016), who found $\mathrm{pH}$ ranges of 6.1 to 8.2, and in line with Arifin et al. (2007) who suggest that the ideal $\mathrm{pH}$ for shrimp farm water is in the range of 7.5 to 8.5 .

It can be seen that all the three treatment tanks showed the same trends in fluctuation overtime. The decrease of $\mathrm{pH}$ between the ninth and fifteenth days was due to the activity of organisms in each treatment tank increasing with molting or skin changes. The highest increases of $\mathrm{pH}$ were found in treatment tank EM4 $7 \mathrm{ml} / \mathrm{l}$, to approximately 8.5 at the end of the observation period. This is consistent with previous research conducted by Suwoyo and Mangampa (2010), which revealed that treatment with probiotics of $1 \mathrm{mg} / \mathrm{l}$ resulted in an average $\mathrm{pH}$ of 7.8 , while $2 \mathrm{mg} / \mathrm{l}$ probiotics increased $\mathrm{pH}$ to about 8 , and so on up to $4 \mathrm{mg} / \mathrm{l}$ resulting in a maximum $\mathrm{pH}$ of 8.2. The main reason for this trend is that the probiotic bacteria can work effectively up to a highest $\mathrm{pH}$ level of 9.

\subsection{Temperature}

Temperature is a parameter in water quality that plays an important role in supporting the lives and growth of shrimp. Extreme temperature change events can disrupt the lives of shrimp and can even lead to death. During the 30 days of observation, temperature in each treatment tank tended to fluctuate, but remained in a stable range of 29.1 to $30.7^{\circ} \mathrm{C}$. This is in line with Haliman and Adijaya (2005), Arifin et al. (2007), and Manan et al. (2016), who found that the optimum temperature for the growth of shrimp lies between $27^{\circ} \mathrm{C}$ and $32^{\circ} \mathrm{C}$. Figure 6 compares the water temperature for each treatment tank.

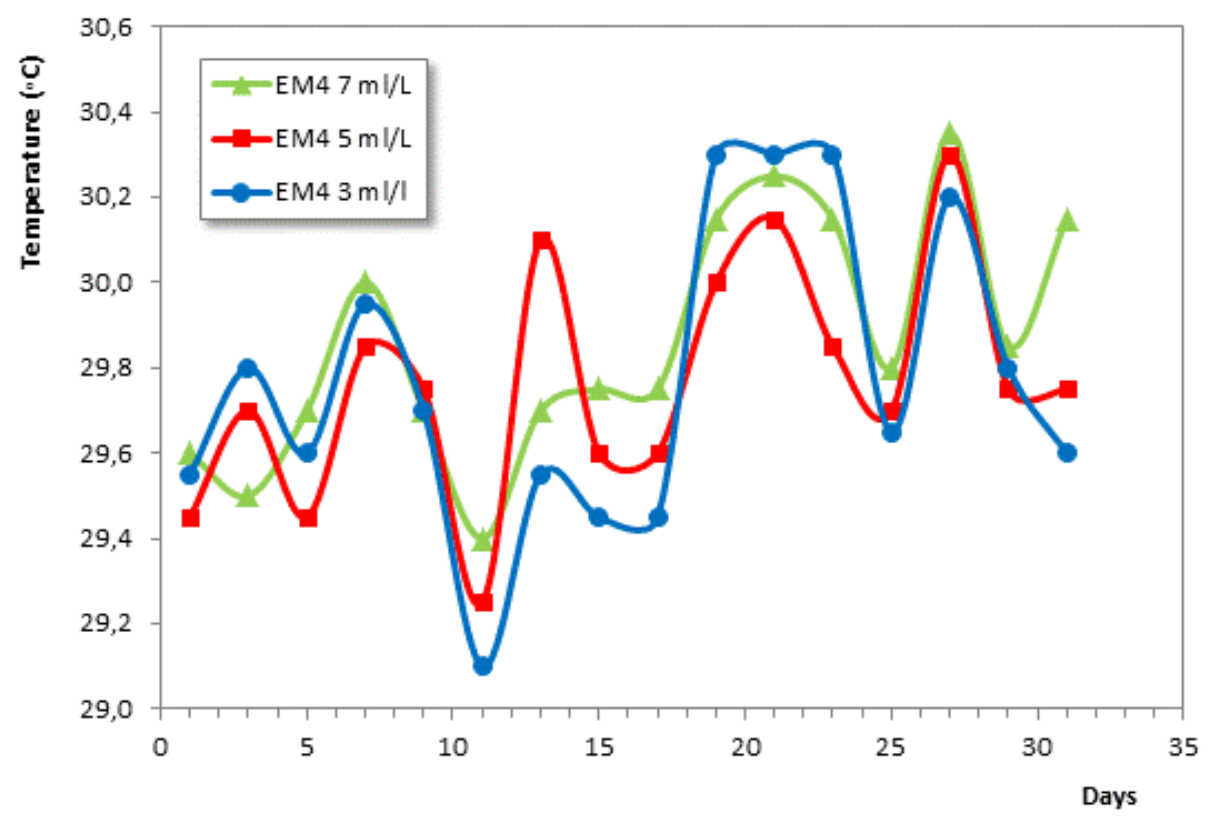

Figure 6 Temperature during the observation period

In general, the temperature changes during the observation period for each treatment tank were found to follow the same tendencies. The fluctuation of temperatures may have been strongly influenced by the weather, as during the observation period there were unstable weather conditions, with frequent change between rain and sun. The maximum temperatures in treatment tanks EM4 $3 \mathrm{ml} / 1,5 \mathrm{ml} / 1$, and $7 \mathrm{ml} / 1$ were measured at $30.3^{\circ} \mathrm{C}, 30.3^{\circ} \mathrm{C}$, and $30.4^{\circ} \mathrm{C}$, respectively, while minimum temperatures were $29.1^{\circ} \mathrm{C}, 29.3^{\circ} \mathrm{C}$, and $29.4^{\circ} \mathrm{C}$, respectively. The maximum and minimum temperature in all three treatment tanks had the same relative values, 
possibly resulting from their being placed in the same location where temperature change was predominantly affected by the weather conditions.

\subsection{Biofloc Formation}

By the end of the observation period, very little biofloc formation was found in the treatment tanks. This was characterized by the presence of bubbles on the surface of the tank water, which indicated that formation of biofloc was starting. Biofloc is formed from the remaining shrimp feed, shrimp feces and shells that have accumulated at the bottom of the tank, and are then decomposed by bacteria. In this study, EM4 bacteria formed exopolysaccharides which later fused together into one floc, known as biofloc. Bubbles representing the biofloc in this study can be seen in Figure 7.

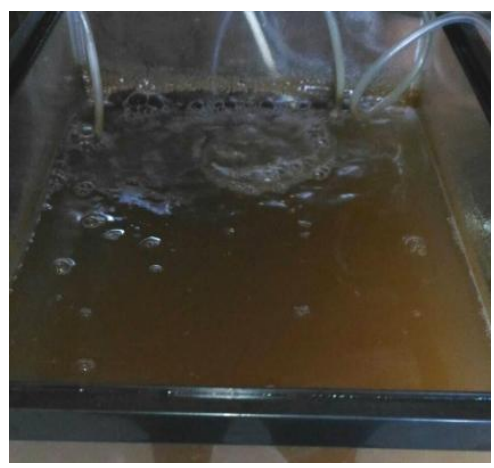

(a)

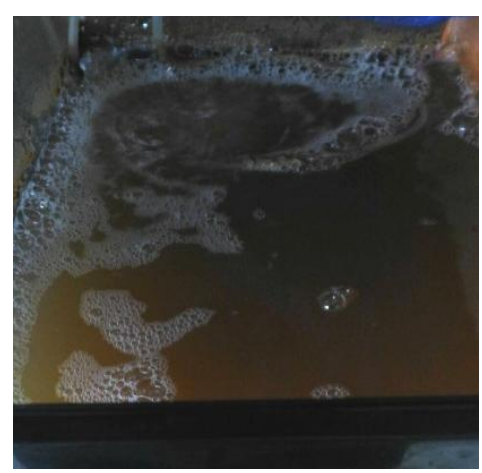

( b)

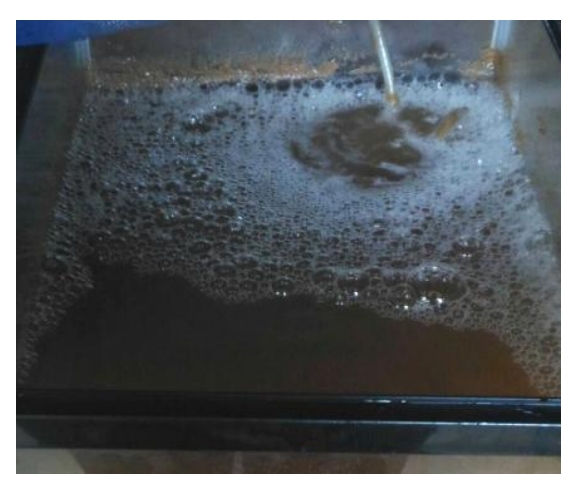

(c)

Figure 7 Bioflocformation ineach treatment tank containingvariations of EM4 concentration: (a) $3 \mathrm{ml} / \mathrm{l}$; (b) $5 \mathrm{ml} / \mathrm{l}$; and (c) $7 \mathrm{ml} / \mathrm{l}$

It can be clearly distinguished that the largest biofloc formation was found in the EM4 $7 \mathrm{ml} / \mathrm{l}$ treatment tank, marked by the appearance of foam floating on the surface of the tank. According to $\mathrm{Ju}$ et al. (2009) microalgae aggregated in the biofloc assimilate ammonia and nitrate in the water and utilize these compounds to build cellular proteins which algae, mainly diatoms, then use themselves, thus providing nutritional feed for the shrimp. As well as oxidizing ammonia, toxicities of nitrate in water can be reduced by bacteria from chemoautotrophic nitrifiers (Kuhn et al., 2010).

Biofloc formation is also strongly influenced by aeration. The aeration process greatly affects the work of bacteria as decomposers, because these organisms require sufficient oxygen for survival. In this study, an aerator with a $7 \mathrm{l} / \mathrm{min}$ capacity was considered as the optimum for providing oxygen for the bacteria to work most effectively in decomposing particulates and forming biofloc. This is in line with Hargreaves (2013) who suggests that shrimp farm water quality can be controlled as long as there is sufficient mixing and aeration to maintain an active floc in suspension.

\subsection{Shrimp Growth}

At the beginning of the observation, each experimental tank contained 20 prawns. The number of prawns was determined by taking into account the shrimp density in the shrimp farm at Fisheries High School (Sekolah Tinggi Perikanan, STP) Serang. Every ten days, the shrimps were weighed to determine the amount of feed needed for the following week, which was about $4 \%$ of the shrimp's weight. This was done to ensure similar treatment of the shrimp and consistency with real field conditions in the shrimp ponds at STP Serang. Shrimp weight over time is presented in Table 2. As can be seen, individual shrimp increased in weight almost three times between each weighing. This significant growth rate may have been caused by the use of EM4 which also served to accelerate the growth of shrimp. 
Table 2 The weight of individual shrimp

\begin{tabular}{cc}
\hline Days & Weight $(\mathrm{g})$ \\
\hline 1 & 0.232 \\
10 & 0.547 \\
20 & 1.329 \\
30 & 3.144 \\
50 & 8.112 \\
\hline
\end{tabular}

This result is in line with research conducted by Rachmawati et al. (2006) who found that the use of EM4 in artificial feed can increase the growth of shrimp. On the fifteenth day after the observation was completed, final weighing was conducted for each tank. About 20 shrimp were immediately weighed to calculate their average weight. It was found that the average weight of individual shrimp was about 6 to 8 grams. This can be considered as a good result, as the average weight of individual shrimp which is considered ideal at age 45-60 days is about 5.1$8.0 \mathrm{~g}$ (Arifin et al., 2007). This is also in line with Manan et al. (2016) who found that shrimp weight after 115 days in biofloc tanks was around 15.7-23 g per individual shrimp.

\section{CONCLUSION}

Biofloc technology combined with an EM4 probiotic can effectively reduce ammonia and nitrate concentration to approximately $0.634 \mathrm{mg} / \mathrm{l}$ and $1.261 \mathrm{mg} / \mathrm{l}$, respectively. EM4 dosage of $7 \mathrm{ml} / \mathrm{l}$ is the optimum concentration for reducing ammonia and nitrate concentration in shrimp pond wastewater, with the highest percentage of removal for ammonia and nitrate being $88.9 \%$ and $83.7 \%$, respectively. Further research is needed to test the effect of higher EM4 concentrations (e.g. $8 \mathrm{ml} / \mathrm{l}-10 \mathrm{ml} / \mathrm{l}$ ) on removal efficiency.

\section{ACKNOWLEDGEMENT}

We would like express our sincere thanks to Environmental Technology Agency (Balai Teknologi Lingkungan), Agency for Assessment and Application of Technology (Badan Pengkajian dan Penerapan Teknologi) for providing the laboratory analysis, and to STP Serang for providing shrimp farm wastewater samples and assistance during this research. Part of this research activity is funded by Directorate Research and Community Engagement Universitas Indonesia under PITTA Grant No. 824/UN2.R3.1/HKP.05.00/2017.

\section{REFERENCES}

Arifin, Z., Kokarkin, C., Priyoutomo, T.P., 2007. Implementation of Best Management Practices (BMP) on Intensive WinduShrimp Cultivation (PenaeusMonodonFabricius). Ministry of Marine Affairs and Fisheries, Directorate General of Aquaculture, Center for Brackish water Aquaculture Development, Jepara, Indonesia (in Bahasa)

Avnimelech,Y., Peter, D.S., Mauricio, E., Kuhn, D., Ray, A., Taw,N., 2012.Biofloc Technology:A Practical Guide Book. 2nd Edn., World Aquaculture Society, Baton Rouge, Louisiana, USA., ISBN: 9781888807219, Pages: 272

Avnimelech, Y., 1999. Carbon/Nitrogen Ratio as a Control Element in Aquaculture Systems. Aquaculture, Volume 176(3-4), pp. 227-235

Avnimelech, Y., 2007. Feeding with Microbial Flocs by Tilapia in Minimal Discharge Bioflocs Technology Ponds. Aquaculture, Volume 264(1-4), pp. 140-147

Black, J.G., 2002. Microbiology. John Wiley \& Sons, Inc. 
deSchryver, P., Verstraete, W., 2009. Nitrogen Removal from Aquaculture Pond Water by Heterotrophic Nitrogen Assimilation in Lab-scale Sequencing Batch Reactors. Bioresource Technology, Volume 100(3), pp. 1162-1167

Haliman, R.W., Adijaya, D.S., 2005. Vannamei Shrimp, Cultivation and Prospects (in Bahasa) Hargreaves, J.A., 2013. Biofloc Production Systems for Aquaculture. SRAC Publication No. 4503, pp. 1-11.Southern Regional Aquaculture Center

Ju, Z.Y., Forster, I.P., Dominy, W.G., 2009. Effects of Supplementing Two Species of Marine Algae or Their Fractions to a Formulated Diet on Growth, Survival and Composition of Shrimp (Litopenaeusvannamei). Aquaculture, Volume 292(3-4), pp. 237-243

Kuhn, D.D., Smith, S.A., Boardman, G.D., Angier, M.W., Marsh, L., Flick Jr., G.J., 2010. Chronic Toxicity of Nitrate to Pacific White Shrimp, Litopenaeusvannamei: Impacts on Survival, Growth, Antennae Length and Pathology. Aquaculture, Volume 309(1/4), pp. $109-114$

Manahan,S.E., 2005. Environmental Chemistry, $8^{\text {th }}$ ed, CRC Press LLC, USA

Manan, H., Moh, J.H.Z., Kasan, N.A., Ikhwanuddin, Mhd., 2016. Biofloc Application in Closed Hatchery Culture System of Pacific White Shrimp, Penaeusvannamei in Sustaining the Good Water Quality Management. Journal of Fisheries and Aquatic Science, Volume 11(4), pp. 278-286

Rachmawati, F.N., Susilo, U., Hariyadi, B., 2006. The Use of EM4 in Artificial Feeds to Increase Feeds Efficiency and Growth of Nila Gift Fish (Oreochromis sp.). J. Agroland, Volume 13(3), pp. 270-274 (in Bahasa)

Samodro, G., 2001. Seedling and Acclimatization Process in Biological Processing Reactor in a Batch Flow System (EM4 37.04 ml/l) and Recirculation System (EM4 4.5 ml/l). Bachelor Thesis. Civil Engineering Study Program, Department of Civil Engineering, Faculty of Engineering, Universitas Indonesia (in Bahasa)

Suwoyo, H.S., Mangampa, M., 2010. Application of Probiotics with Different Concentrations on Vannamei Shrimp Maintenance (LitopenaeusVannamei). In: Proceeding Innovation Forum of Aquaculture Technology (in Bahasa) 